\begin{tabular}{lrr}
\hline \hline VOLUME 2 & No. 1 (April 2019) & Page 9-13 \\
\hline \hline
\end{tabular}

\title{
Analisis Puisi Pada Hari Minggu Kucari Ayah ke Kota Karya Hasan Aspahani Ditinjau dari Aspek Semiotik
}

\author{
Sheyla Adeline, Syaiful Arifin, Tri Indrahastuti \\ Universitas Mulawarman \\ Universitas Mulawarman \\ Universitas Mulawarman \\ Email: sheylabtg26@gmail.com
}

\begin{abstract}
This study aims to describe the shape of the icons, indexes, and symbols contained in the poem On Sunday I'm Looking For My Father To The City. The method used in this research is a qualitative approach method. Data collection techniques used are library research techniques, reading techniques, note-taking techniques, and semi-structured interview techniques. The data analysis techniques used is to understand the data as a whole, classify the data,make comparisons of data matches, and draw data conclusions. The results of this study include (1) Icons in the poem On Sunday I Look for Father to The City by Hasan Aspahani there two types of icons, namely image icons and diagrammatic icons.(2) The index in the poem On Sunday I'm Looking for My Father to The City by Hasan Aspahani is an index in various findings between texts.(3) Symbols in Hasan Aspahani's poem On Sunday I Look for Father to the City are signs that do not show a casual relationship between the signifier and the signifier.
\end{abstract}

Keywords: poetry, semiotic study

\section{PENDAHULUAN}

Definisi tentang sastra tergantung pada konteks, cara pandang, wilayah geografi, budaya, waktu, tujuan, dan juga berbagai faktor yang lain. Oleh karena itu, upaya mendefinisikannya akan selalu saja gagal karena definisi yang dicoba dirumuskan ternyata memiliki pengertian yang kurang sempurna dibanding yang didefinisikannya. Welllek dan Warren (1993) (dalam Wiyatmi, 2006: 14) telah mencoba mengemukakan beberapa definisi sastra. Pertama, sastra adalah segala sesuatu yang tertulis atau tercetak. Dengan pengertian demikian, maka segala sesuatu tertulis, entah itu ilmu kedokteran, ilmu sosial, atau apa saja yang tertulis adalah sastra. Kedua, sastra dibatasi hanya pada "mahakarya" (great books), yaitu buku-buku yang dianggap menonjol karena bentuk dan ekspresi sastranya. Ketiga, sastra diterapkan pada seni sastra, yaitu dipandang sebagai karya imajinatif.

Salah satu media karya sastra yang menggunakan media bahasa sebagai perantaranya diantaranya adalah puisi. Puisi sebagai salah satu karya seni sastra yang dapat dikaji melalui berbagai macam aspek. Puisi juga dapat dikaji melalui struktur dan unsur-unsurnya mengingat bahwa puisi itu adalah struktur yang tersusun dari berbagai macam unsur dan sarana kepuitisan. Kepuitisan dapat dicapai dengan bermacammacam cara misalnya dalam puisi bersifat estetis pada unsur puisi untuk menambahkan keindahan sebagai wujud komunikasi satu arah. Meskipun demikian, banyak orang yang tidak dapat memahami puisi secara sepenuhnya tanpa mengetahui dan menyadari bahwa puisi itu karya estetis yang bermakna, yang memiliki arti bukan hanya suatu karya tanpa makna. Oleh karena itu, 
sebelum mengkaji aspek-aspek yang lain, perlu lebih dahulu puisi dikaji sebagai sebuah struktur yang bermakna dan bernilai estetika.

Puisi Pada Hari Minggu Kucari Ayah ke Kota dipilih oleh penulis karena karya tersebut salah satu puisi dari Hasan Aspahani. Beliau merupakan seorang penyair Indonesia yang berasal dari Kutai Kartanegara, Kalimantan Timur. Beberapa karyanya masuk hingga lima besar di Kusala Sastra Khatulistiwa. Pada tahun 2019, buku puisinya Aviarium (Gramedia Pustaka Utama, 2019) terpilih sebagai buku puisi terbaik dalam Anugrah Hari Puisi Indonesia. Puisi Pada Hari Minggu Kucari Ayah ke Kota merupakan salah satu puisi yang dimuat dalam buku Aviarium. Dari sekian banyak puisi karya sastrawan lain, puisi ini dipilih karena tema yang diangkat dalam puisi tersebut sangat unik dan menarik untuk diteliti.

Berdasarkan uraian diatas, peneliti menjadikan puisi Pada Hari Minggu Kucari Ayah ke Kota sebagai objek penelitian karena menarik untuk dipahami maknanya lebih lanjut, sehingga makna yang tersirat dalam puisi tersebut dapat terungkap secara menyeluruh. Peneliti yakin, banyak makna yang dapat diungkap dalam puisi tersebut. Oleh sebab itu, puisi Pada Hari Minggu Kucari Ayah ke Kota akan di kaji menggunakan analisis semiotik.

Analisis semiotik merupakan metode menganalisis karya sastra yang mengkaji melalui tanda dan simbolisasi yang terdapat dalam karya sastra.

Dalam analisis semiotik, karya sastra dipandang sebagai proses penuangan imajinasi pengarang. Maka dari itu, karya sastra dikaitkan dengan pengarang, realita pembaca, dan hal-hal yang berkaitan dengan karya sastra tersebut. Dalam penelitian ini penulis cenderung kepada teori C.S Peirce yang memfokuskan pada tanda yang bersifat ikon, indeks, dan simbol.Atas dasar tersebut penulis beranggapan bahwa sangat penting dilakukan penelitian karya sastra berupa puisi pada kajian semiotika, mengingat penelitian ini dapat dijadikan sarana menggali makna dalam sebuah karya sastra yang dapat di aplikasikan langsung kedalam kehidupan.

\section{METODE PENELITIAN}

Penelitian ini adalah kumpulan puisi karya Hasan Aspahani. Puisi yang dibahas akan diambil dari buku Aviarium karya Hasan Aspahani. Penelitian ini digolongkan ke dalam jenis penelitian kualitatif, dimana penelitian ini menghasilkan data deskriptif.
Bogdan dan Taylor (dalam Moleong, 2017: 6) menjelaskan bahwa penelitian kualitatif adalah salah satu prosedur penelitian yang menghasilkan data deskriptif berupa kata-kata tertulis atau lisan dari orang-orang dan perilaku yang dapat diamati. Pendekatan ini diarahkan pada latar dan individu tersebut secara holistik (utuh). Sumber data dalam penelitian ini adalah kumpulan puisi didalam buku Aviarium karya Hasan Aspahani, yang diterbitkan pada tahun 2019 oleh PT Gramedia Pustaka Utama.

Menurut Sugiyono (2018: 104), pengumpulan data dapat dilakukan dalam berbagai setting, berbagai sumber, dan berbagai cara. Dalam pengumpulan data, digunakan beberapa teknik pengumpulan data sebagai berikut. (1) Teknik penelitian pustaka. Sasaran penelitian ini adalah bahan tertulis bahwa dalam bentuk penejelasan aspek fokus penelitian, kajian kepustakaan mesti menampilkan penjelasan teoritis dan konseptual mengenai aspek-aspek yang akan di kaji, terutama yang terkandung dalam fokus utama penelitian yang akan dilakukan (Ibrahim: 2015: 37). (2) Teknik baca, yaitu penulis membaca puisi Pada Hari Minggu Kucari Ayah ke Kota Karya Hasan Aspahani secara berulang-ulang untuk menentukan gambaran makna yang terdapat dalam naskah puisi.(3) Teknik mencatat, yaitu data yang relevan dengan objek penelitian dikumpulkan atau dicatat. Pengumpulan data dilakukan dengan mencatat kalimat-kalimat yang berhubungan dengan penelitian.(4) Teknik wawancara, dilakukan dengan cara penyampaian sejumlah pertanyaan dari pewancara. Wawancara digunakan sebagai teknik pengumpulan data apabila peneliti ingin melakukan studi pendahuluan untuk menemukan permasalahan yang harus diteliti, tetapi juga apabila peneliti ingin mengetahui halhal dari responden yang lebih mendalam. Teknik pengumpulan data ini mendasarkan diri pada laporan tentang diri sendiri atau self-report, atau setidak-tidaknya pada pengetahuan dan atau keyakinan pribadi (Sugiyono, 2018: 114) yang dipilih dalam wawancara adalah teknik wawancara semiterstruktur, dimana pelaksanaannya lebih bebas bila dibandingkan dengan wawancara terstruktur. Tujuan dari wawancara semiterstruktur adalah untuk menemukan permasalahan secara lebih terbuka, di mana pihak yang diajak wawancara diminta pendapat dan ide-idenya. Dalam melakukan wawancara semiterstruktur ini, peneliti perlu mendengarkan secara teliti dan mencatat apa yang dikemukakan oleh informan. Peneliti akan mewancarai pengarang puisi Pada Hari Minggu Kucari Ayah ke Kota yaitu Hasan Aspahani. 


\section{HASIL DAN PEMBAHASAN}

Analisis data di sini dibagi menjadi 11 bagian sesuai dengan puisi Pada Hari Minggu Kucari Ayah ke Kota yang terdiri dari 11 bagian. Pembagian ini dilakukan agar memudahkan analisis maka selanjutnya akan menggunakan istilah data seperti data satu, data dua, data tiga sampai dengan data sebelas.

Sesuai dengan penelitian maka analisis data difokuskan pada tanda ikon, indeks, dan simbol yang terdapat pada puisi Pada Hari Minggu Kucari Ayah ke Kota yang akan dianalisis sebagai berikut.

\section{Ikon}

Ikon ada kemiripan antara acuannya dengan tanda. Tanda tersebut memang mirip dengan acuannya atau merupakan gambar/arti langsung dari petanda. Misalnya foto merupakan gambarang langsung dari orang yang difoto.

a) Ikon Topografis (Imagi)

Berdasarkan persamaan tata ruang ikon topografis adalah tanda yang bersifat ikonis dengan kualitas yang simple berupa puisi, gambar, dan karya seni rupa pada umumnya dan mampu menunjukkan kemiripan citrawi dengan objek yang diacunya. Misalnya puisi-puisi kongkret atau visual.

\section{(Baris 1) KAMUS besar adalah kota kata-kata}

Pada baris pertama kata KAMUS besar adalah kota kata-kata merupakan suatu tanda yang mengambil bagian dalam karakter objek atau suatu tanda yang kualitasnya mencerminkan objeknya. Klausa KAMUS besar adalah kota kata-kata dikatakan sebagai penanda. Sedangkan petandanya adalah kota yang banyak memiliki kumpulan kata-kata yang memuat khazanah secara lengkap. Disini penyair mengunakan citra penglihatan untuk kota kata-kata.

\section{(Baris 2) Pada hari Minggu aku mencari ayah ke} sana

Pada baris ke-2 kata mencari merupakan suatu tanda yang mengambil bagian dalam karakter objek atau suatu tanda yang kualitasnya mencerminkan objeknya. Klausa Pada hari Minggu aku mencari ayah ke sana dikatakan sebagai penanda. Sedangkan petandanya adalah tokoh $a k u$ yang kehilangan ayahnya, mencari ayahnya ke kota tersebut. Disini penyair menggunakan citra gerak untuk kata mencari.

\section{(Baris 17) Aku pergi ke kota, kota kata-kata}

Pada baris ke-17 kata pergi merupakan suatu tanda yang mengambil bagian dalam karakter objek atau sebagai suatu tanda yang kualitasnya mencerminkan objeknya. Klausa $A k u$ pergi ke kota, kota kata-kata dikatakan sebagai penanda. Sedangkan petandanya adalah si aku yang mau berangkat ke kota yang dimana kota tersebut memiliki banyak para petinggi. Disini penyair menggunakan citra gerak untuk kata pergi.

\section{(Baris 18) pada hari Minggu, mencari ayah}

Pada baris ke-18 kata mencari merupakan suatu tanda yang mengambil bagian dalam karakter objek atau suatu tanda yang kualitasnya mencerminkan objeknya. Klausa pada hari Minggu, mencari ayah dikatakan sebagai penanda. Sedangkan petandanya adalah si $a k u$ menyusuri kota untuk mencari ayahnya pada hari Minggu. Disini penyair menggunakan citra gerak untuk kata mencari.

\section{b) Ikon Diagramatis}

Ikon yang menampilkan relasi-relasi, terutama relasi diadik. Pengertian Pierce mengenai diagram ini kira-kira sama seperti yang kita pahami dalam bahasa sehari-hari. Sesuai dengan kriteria ikon diagramatis yang telah dijabarkan diatas, maka yang termasuk ikon diagramatis tersebut adalah

(Baris 16) Ia juga tak berkata apa-apa ketika aku pamit meninggalkannya

Kriteria ikon diagramatis adalah tanda yang menggantikan sesuatu semata-mata karena ia mirip dengan objeknya, dan membangkitkan sensasi analog di dalam bentuk lantaran kemiripannya atau dapat juga berupa uruta kata demi kata atau peristiwa demi peristiwa.

Pada baris ke-16 kalimat Ia juga tak berkata apa-apa ketika aku pamit meninggalkannya secara diagramatis mengurutkan peristiwa demi peristiwa yang ingin di deskripsikan oleh penulis melalui larik-larik yang berkesesuaian dengan pergeseran waktu.

\section{Indeks}

Indeks, istilah ini berarti bahwa antara tanda dan acuannya ada kedekatan eksistensial. Penanda merupakan akibat dari petanda (hubungan sebab akibat). Dalam hal ini, Pierce menunjukkan indeksikal teks melalui tiga sisi, yaitu: pengarang sebagai ciri komunikasi, dunia nyata sebagai ciri nilai-nilai pengetahuan, dan pembaca dengan ciri nilai-nilai eksistensial. Indeks dapat teraktualisasikan di dalam kata penunjuk (demonstratives) seperti ini, itu, di sini, di situ,dan seterusnya; kata ganti personal (personal pronoun) seperti aku, engkau, dan seterusnya. 
Berdasarkan pengertian tersebut, maka yang termasuk di dalam indeks adalah sebagai berikut

(Baris 2) Pada hari Minggu aku mencari ayah ke sama

Pada baris ke-2 merupakan sebuah indeks yang kaitannya dengan antarteks. Kata $a k u$ merupakan sebuah indeks yang teraktualisasikan berupa kata ganti personal yang merujuk kepada si penyair yang mencari Ayahnya.

(Baris 7) Hendak mengemis, tampangku buruk ketimbang memberi maras

Pada baris ke-7 merupakan sebuah indeks yang kaitannya dengan antarteks. Frasa tampangku merupakan sebuah indeks yang teraktualisasikan berupa kata ganti personal yang merujuk kepada kata $a k u$.

(Baris 14) "Ibu, apakah benar namamu Pertiwi?"

Pada baris ke-14 merupakan sebuah indeks yang kaitannya dengan antarteks. Frasa nатати merupakan sebuah indeks yang teraktualisasikan berupa kata ganti personal. Frasa namamu merujuk kepada tokoh $i b u$.

(Baris 15)Ibu tetap saja dengan bahasanya yang diam itu

Pada baris ke-15 merupakan sebuah indeks yang kaitannya dengan antarteks. Kata itu merupakan sebuah indeks yang teraktualisasikan berupa kata petunjuk untuk menunjukkan bahwa tokoh $i b u$ tetap saja dengan bahasanya diam saat tokoh $a k u$ berbicara kepada ibunya.

\section{Simbol}

Simbol penanda tidak merupakan sebab atau akibat dan tidak merupakan gambaran langsung dari petanda tetapi hubungan antara tanda dan acuannya telah terbentuk secara konvensional. Jadi, sudah ada persetujuan antara pemakai tanda dengan acuannya.

\section{Baris 5) Aku hidup bersama bahasa ibu yang lebih banyak diam}

Pada baris ke-5, kata bahasa ibu sesuai dengan kriteria tanda simbol dalam semiotik, yaitu tidak menunjukan sebab-akibat. Kata bahasa ibu di dalam Kamus Besar Bahasa Indonesia adalah bahasa pertama yang dikuasai manusia sejak lahir melalui interaksi dengan sesama anggota masyarakat bahasanya, seperti keluarga dan masyarakat lingkungannya. Bahasa $i b u$ juga sesuai dengan kriteria simbol yang didasarkan pada konvensi atau kesepakatan bersama. Sehingga kata bahasa ibu dalam konvensi sastra dimaknai sebagai gambaran tentang bahasa yang pertama dipakai dalam komunikasi pertama seorang anak dengan orang tuanya sebagai alat komunikasi sehari-sehari tetapi pada baris ke-5 ini tokoh aku yang hidup bersama bahasa ibu yang lebih banyak diam sehingga menyebabkan tokoh aku seperti anak yang tak jelas, yatim bukan piatupun bukan seperti dideskripsikan pada baris ke-6.

\section{(Baris8)Hendak menangis, orang bilang air} mataku sandiwara palsu

Pada baris ke-8, kata sandiwara palsu sesuai dengan kriteria tanda simbol dalam semiotik, yaitu tidak menunjukkan sebab-akibat. Kata sandiwara di dalam Kamus Besar Bahasa Indonesia pertunjukan lakon atau cerita (yang dimainkan oleh orang). Kata palsu di dalam Kamus Besar Bahasa Indonesia curang; tidak jujur. Sandiwara palsu juga sesuai dengan kriteria simbol yang didasarkan pada konvensi atau kesepakatan bersama. Sehingga kata sandiwara palsu dalam konvensi sastra dimaknai sebagai gambaran tentang seseorang yang melakukan perbuatan yang tidak jujur seperti yang didekripsikan pada baris ke-8 Hendak menangis, orang bilang air mataku sandiwara palsu.

\section{(Baris 11) Dengan puisi yang yang belum rampung}

Pada baris ke-11, kata rampung sesuai dengan kriteria tanda simbol dalam semiotik, yaitu tidak menunjukan hubungan sebab-akibat. Kata rampung memiliki arti selesai di dalam Kamus Besar Bahasa Indonesia. Rampung juga sesuai dengan kriteria simbol yang didasarkan pada konvensi atau kesepakatan bersama. Sehingga kata rampung pada konvensi sastra dimaknai sebagai gambaran mengenai ada suatu hal yang belum terselesaikan yang dideskripsikan pada baris ke-11 ini.

\section{(Baris 14)"Ibu, apakah benar ramamu pertiwi?"}

Pada baris ke-14, kata pertiwi sesuai dengan kriteria tanda simbol dalam semiotik, yaitu tidak menunjukan hubungan sebab-akibat. Kata pertiwi memiliki arti tanah air di dalam Kamus Besar Bahasa Indonesia. Pertiwi juga sesuai dengan kriteria simbol yang didasarkan pada konvensi atau kesepakatan bersama. Sehingga kata pertiwi pada konvensi sastra dimaknai sebagai gambaran dimana tokoh aku mempertanyakan apa benar ini tanah air kita yang dideskripsikan pada baris ke-14 ini. 


\section{(Baris 20) di kaki lima}

Pada baris ke-20, kata kaki lima sesuai dengan kriteria tanda simbol dalam semiotik, yaitu tidak menunjukan hubungan sebab-akibat. Kata kaki lima memiliki arti toko di pinggir jalan (biasanya berukuran lima kaki, biasanya dipakai sebagai tempat berjualan) di dalam Kamus Besar Bahasa Indonesia. Kaki lima juga sesuai dengan kriteria simbol yang didasarkan pada konvensi atau kesepakatan bersama. Sehingga kata kaki lima pada konvensi sastra dimaknai sebagai gambaran penjaga dagangan yang melakukan kegiatan komersial di atas daerah milik jalan.

\section{KESIMPULAN}

Berdasarkan hasill peneliitian yang penulis peroleh, dapat disimpulkan bahwa analisis semiotika puisi Pada Hari Minggu Kucari Ayah ke Kota Karya Hasan Aspahani sebagai berikut.

1. Ikon yang ditemukan dalam puisi Pada Hari Minggu Kucari Ayah ke Kota ada dua jenis ikon, yaitu ikon imagi dan ikon diagramatis.

2. Indeks yang ditemukan dalam puisi Pada Hari Minggu Kucari Ayah ke Kota ialah indeks dalam kaitannya dengan antarteks.

3. Simbol yang ditemukan dalam puisi Pada Hari Minggu Kucari Ayah ke Kota karena tanda tidak menunjukkan hubungan sebabakibat antara penanda dan petandanya

\section{UCAPAN TERIMA KASIH}

Penelitian ini dapat dilaksanakan dengan baik dan lancar berkat bantuan dari berbagai pihak, untuk itu peneliti ingin mengucapkan terima kasih kepada Dosen-dosen Pembimbing yang sudah bersedia membimbing dan peneliti juga ingin mengucapkan terima kasih kepada pengarang puisi Bapak Hasan Aspahani yang sudah bersedia menjadi informan di penelitian ini.

\section{REFERENSI}

Aspahani, Hasan. (2019). Aviarium. Jakarta: PT. Gramedia Pustaka Utama.

Hoed, Benny H. (2014). Semiotik dan Dinamika Sosial Budaya. Depok: Komunitas Bambu.

Moleong, Lexy J. (2017). Metodologi Penelitian Kualitatif. Bandung: PT. Remaja Rosdakarya.

M. A, Ibrahim. (2015). Metodologi Penelitian Kualitatif. Bandung: Alfabeta,cv.

Nyoman, Kutha Ratna. (2015). Teori, Metode, dan Teknik Penelitian Sastra. Yogyakarta: Pustaka Pelajar.
Pradopo, Rachmat Djoko. (2020). Beberapa Teori Sastra, Metode Kritik, dan Penerapannya. Yogyakarta: Gadjah Mada University Press.

Rokhmansyah, Alfian. 2014. Studi dan Pengkajian Sastra. Yogyakarta: Graha Ilmu.

Santosa, Puji. (2013). Ancangan Semiotika dan Pengkajian Susastra. Bandung: Angkasa.

Semi, M. Atar. (1990). Metode Penelitian Sastra. Bandung: Penerbit Angkasa.

Sugiyono. (2018). Metode Penelitian Kualitatif. Bandung: Alfabeta.

Zaimar, Okke Kusuma Sumantri. (2014). Semiotika dalam Analisis Karya Sastra. Depok: PT Komodo Books. 